\title{
In Search for Balance between \\ Constitutional Human Rights and Their Limitations: Management of Covid-19 Pandemic Crisis in Slovenia
}

\author{
SAŠA ZUPAN KORŽE \\ Vanadis Ltd, Slovenija, Slovenia \\ sasa.zupan@vanadis.si
}

\begin{abstract}
Non pharmaceutical measures adopted by the governments in the world to cease the spread of the Covid-19 have limited some of the basic human rights of citizens and businesses. Temporary limitation of movement, socializing and performing the business are only some of them. The purpose of this paper is to synthesize and critically discus how the Government of the Republic of Slovenia managed the crisis of Covid-19 epidemic in the state in spring 2020. The synthesis and discussion are based on the review of the events in Slovenia assessed through the interpretation of human right lens. The results show how the law technique was used to manage Covid-19 pandemic. Furthermore, they reveal that there is a thin line between justifiable protection of the public interest to cease the spread of the virus and unjustifiable limitations of the constitutional rights. The study contributes to the evolving literature on crisis management with law technique and on protection of human rights in exceptional circumstances.
\end{abstract}

Key words: regulations, covid-19, pandemic, constitutional rights, crisis management

(c) BY-SA https://doi.org/10.26493/1854-4231.15.99-120

\section{Introduction}

In the first quarter of 2020, governments around the world introduced unprecedented temporary measures to tackle the Covid-19 crisis: restrictions of movement of people, shutdown of non-essential businesses, limitation of people-to-people interactions etc. (Organisation for Economic Co-Operation and Development 2020). Rapid, stringent and pervasive non-pharmaceutical measures (Ryan 2020) have risen several legal dilemmas if - and to what extent - they have or might have been justifiable to limit basic human rights. In some cases, the measures restricting enjoyment of human rights and war 
rhetoric that accompanies them have opened the way to the abuse of emergency regulations and overreach of executive power. Therefore, the pandemic and the response to it are putting to the test human rights (Spadaro 2020). A growing number of literature has been emerging to discuss this issue (e.g. Amon 2020; Amon and Wurth 2020; Sparado 2020; Valerio 2020). As billions of people around the world have been put under some sort of lockdown, concerns about the impact of such measures on human rights have been raised by United Nations' High Commissioner for Human Rights (Office of the United Nations High Commissioner for Human Rights 2020a) and other human experts (Office of the United Nations High Commissioner for Human Rights 2020b).

To contain the Covid-19, the Government of the Republic of Slovenia (in continuation: Government) has implemented several measures that strongly affected basic human rights of the citizens. Some legal and constitutional experts have expressed doubt that all measures to contain the virus (e.g. limitation of people's movement within the borders of the municipality of their residence) were justifiable, scientifically based, proportionate and necessary (e.g. Teršek, 2020b; Trampuš 2020a; Vuksanović 2020b; 2020c). Additionally, certain attempts of the Government to extend its authority during the epidemic time might have created a feeling that the Government have tried to use legitimate goals for nonlegitimate transfer of the power from the legislative to the executive body (a case of Hungary) and to increase the control over the citizens (Zimic 2020). Consequently, several proposals have been filed to the Constitutional court to decide on the conformity of the regulations of the Government adopted during Covid-19 pandemic with the constitutional provisions (Teršek 2020).

The goal of the study is threefold. First, the study highlights how extensively the Government used laws and regulations to manage the Covid-19 pandemic in Slovenia, accompanied by the war rhetoric. Second, it reveals what kind of human rights were affected by restrictions. The third goal is to highlight the polarisation of legal opinions toward the restrictive measures of the Government in the case of Constitutional Court decision from August 2020.

\section{Theory}

Although the Covid-19 pandemic may not prove to be the worst pandemic in history, almost all affected countries have imposed extremely strict restrictions of private and economic life to contain the virus (Meßershmidt 2020). States and international institutions 
have adopted a set of the following emergency measures: restricting travelers from countries with high infection rates, preventing interand intra-state movement, quarantine, isolation, surveillance, using mobile telephone data, contact tracing digital apps etc. The majority of people in the world have been faced with stay-at-home orders, limitations on the number of people assembled in one place and other restrictions of public gatherings, work-from-home orders, education-from-home orders, closing non-essential businesses etc. (Richardson and Divine in press).

Meßershmidt (2020) points out that strong reaction dedicated by the Covid-19 crisis do not only reflect the severity of the crisis, but also points to the growing influence of precautionary principle. States used the 'better safe than sorry' approach, although this principle does not supplant the principle of proportionality. Precautionarity sets limits to risk-related legislation even though it allows restrictions in the absence of scientific consensus. Precautionary principle can help to maintain (or restore) rationality and prudent risk trade-offs even in times of emergency legislations.

With the above mentioned measures, states created a unique social experiment with an uncertain outcome (Meßershmidt 2020). Subsequently, the limitations of people's rights to the extent that has been unprecedent in democratic countries in time of peace raised important question of international human rights (Spadaro 2020). If human rights are limited, substantive claims brought by individuals complaining about the restrictions adopted can be adjudicated in terms of their legality, necessity and proportionality with the regards of the identified legitimate aim (Spadaro 2020).

As international legal order is structured around the principle of state sovereignty, states authorities have the monopoly on the legitimate use of physical force in their territory (Lebret 2020). However, the state's power is not limitless: 'International Covenant on Civil and Political Rights' (1967) imposes conditions under which limitation or derogation of human rights can be justified. For Eu member states, human rights are also subject of the 'European Convention on Human Rights' (1950) which is - according to the European Court of Human Rights - qualified as an 'instrument of European public order'.

In theory and practice, there is distinctive difference between the group of absolute human rights (e.g. right to life, no torture, no slavery etc.) and the group of non-absolute human rights. While the rights in the first group cannot be derogated at all, the rights from the second group can be limited or derogated, but only for valid 
purposes ('International Covenant on Human and Political Rights' 1967). Non-absolute human rights are allowed to be limited if they are prescribed by the law, when they pursue a legitimate aim, when such limitations are necessary in a democratic society and proportionate to identified legitimate aim. That means that no other less restrictive alternative is available. Limitations allow precisely for the balancing of individual and collective interests (Spadaro 2020).

From the beginning of the Covid-19 pandemic, several scholars have discussed the relation between protecting human rights and containment measures for ending the Covid-19 crisis. Spadaro's (2020) study has been selected as one of the best examples to highlight how human rights are interdependent while at the same time reflecting competing interest that are sometimes hard to reconcile.

Spadaro (2020) points out that even the Covid-19 pandemic itself threaten the enjoinment of human rights, particularly the right to live and the right to die. The states have a due diligence obligation to protect individuals from deprivation of life caused by another person. In Covid-19 pandemic this obligation means protection of individuals from threat to life posed by others carrying an infection. The obligation of the states to ensure the right to life also encompasses foreseeable threats and taking measures to address life-threating disease. The prevention and treatment of epidemics are also facets of the right to health and the right of access to healthcare.

The pandemic underlines the necessity of upholding the rights to life and health in order for the normal life of a pandemic society and shows the tension between these and other rights. The tension is caused by the scare resources to address and manage the pandemic on one side and by competition between individual and collective interest. Thus, public health measures clash with a number of individual rights e.g. freedom of movement, particularly restricted movement within the borders of a state/region/municipality or even within the walls of the apartment or house, so-called shelterin-place orders. Furthermore, the enjoyment of the right to personal freedom is affected by the imposition of mandatory quarantine for the passengers coming from abroad or by imposition of isolation to the people suspected or known to be positive. Prohibition of public gathering affects freedom of assembly and association. Some surveillance measures aim at tracing contacts by using mobile data and artificial intelligence tools. Those measures pose a challenge to full enjoyment of the right to private life. The closure of place of worship affected the human right to religion. The closure of businesses and workplace also has consequences on the right to work, espe- 
cially for workers in the informal economy and for those who cannot work from home (Spadaro 2020).

Spadaro (2020) points out that the law allows some limitations of non-absolute human rights for the protection of public health. Therefore, governments can use some limitations or derogations of those to address the exceptional character of the pandemic. However, it is of paramount importance that the measures are limited - materially and temporally - to what is strictly necessary to manage the pandemic. However, in any case two rights cannot be suspended: the right to information and the right to freedom of expression. Those rights allow constant monitoring of the legitimacy, necessity and proportionality of the containment measures taken by governments in relation to their impact on human rights.

It is of paramount importance that interferences with fundamental human rights should be viewed with caution, if no suspicion. Limitations should not be used to promote power grabs, quash dissent or prosecute minorities. Therefore, constant scrutiny should be applied by national courts, legislative bodies and civil societies to all governmental initiatives. Instead of using continued restrictions or suspensions of human rights, states should adopt a long-term strategy to manage the pandemic (Spadaro 2020).

In some studies, the 'war metaphors' were pointed out to present the way some state leaders (e.g. French president Emmanuel Marcon, USA president Donald Trump) wanted to emphasize the exceptional nature of the situation of the Covid-19 pandemic. Linguistic and communication experts diverge such rhetoric. For one group, war rhetoric is not unusual in the medical area (e.g. 'fighting cancer'). Furthermore, it makes clear about the severity of Covid-19 situations and allows gathering the nation together toward the same objective. On the other hand, war metaphors might serve as a political justification of serious human rights limitations (Lebret 2020). War rhetoric can suggest that the outbreak should be designated as an armed attack, which should be followed by the war-like responses to the pandemic, taking the measures that severely limit the enjoyment of personal freedom (Spadaro 2020).

However, French philosopher Lebre thinks that military reaction toward pandemic is inaccurate and inappropriate. War is a legal concept in which virus cannot be an enemy. With war rhetoric, politicians only reveal their short-sightedness, in which they understand security and protection only in the form of police and the army, while they do not know how to anticipate real threats (Podkrižnik 2020).

In particular, Spadaro (2020) emphasizes that the curtailment of 
human rights should not become a new normal. The Covid-19 pandemic should not create a world where human rights have lost all significance (Spadaro 2020), as there have already been evidences even in the $\mathrm{EU}$. In the $\mathrm{EU}$, certain governments used the Covid-19 crisis as an opportunity for more autocratic way of leading their states. Drinóczi and Bień-Kacała (2020) pointed out the example of Hungary and Poland, where governments already apply the non-liberal version of the Rule of Law (illiberal legality) and exploited Covid19 pandemic for political gain. In Hungary, a case of constitutional bypassing has been done during the pandemic for enabling leaders to pursue their ideas. Those ideas can more smoothly be achieved in the pretense of fighting against a human pandemic than in usual situations.

The practice of Hungary was not left unnoticed by the $\mathrm{E} u$. Therefore, the Council of Europe (2020) emphasised that measures of $\mathrm{EU}$ member states in the pandemic must comply with both national constitutions and international standards and must observe the very essence of democratic principles.

The Covid-19 situation can be viewed as an example of confrontation between the logic of power (public order and peace) and the power of the logic (rule of law) (Zupančič 2004). In a usual social situation, when the government operates stably, there will be greater emphasis on the rule of law. However, when society is threatened, there will be greater emphasis on public order and peace. The 'rule of law' recedes a little, but is still present. The question is to what extent it will recede in Covid-19 pandemic.

\section{Methods}

Integrated review, content analysis and description have been used as the methods for collecting and processing data and for presenting the results of the study. The selected methods were identified as the most appropriate combination according to the qualitative nature of the data, the research topic, the purpose and the goals of the research, the novelty of the topic and in terms of the period in which study was prepared.

Following Snyder (2019), the method of integrative literature review was used for data collection. This method allows for a more creative approach from systemic or semi-systematic literature review: it does not cover all literature that has ever been published on a research topic but combines different perspectives on it. The method was identified as the most appropriate for obtaining data for achieving the research goals. 
Data were collected from secondary sources. The process was designed to prepare relevant and quality set of documents, which included steps, criteria and guidelines taken from existing qualitative studies, adapted to this research. We defined the time frame for the relevant documents, the data-bases for their collection, the search key-words and the selection process for further analysis. The documents, published in Slovene language, online and offline, in the period from January until the middle of October 2020, were collected. The documents were searched in the relevant daily news, weekly magazines, and legal journals, in statements of relevant legal experts, opinions and researches, in Official Gazette and PISRS data base and other relevant research-related publications.

A selection of the collected documents was performed in the next step. First, we eliminated the documents that did not contribute to the results of the research. Then, we studied the content of the selected documents according to specific goals of the study. The final selection was processed using the content analysis method, following the guidelines of Miles, Huberman, and Sandaña (2004), how to analyze qualitative data.

\section{Findings}

The finding section is divided to two subsections. In the first one, the regulations that restricted human rights of Slovenes are presented, accompanied by some comparison with other $\mathrm{EU}$ member states and by some of legal and medical experts. The focus of the second subsection is on the process, decision and comments of the Constitutional Court about intra-municipality movement of people.

\section{Restrictive Measures Implemented by Government of Republic of Slovenia}

CONTEXT

As EU member states did not confer a competence to the $\mathrm{EU}$ in public health, the decision of how to manage the Covid-19 pandemic was sovereign jurisdiction of the member states (Lebret 2020). In order to achieve common objectives, the EU could only support, coordinate or supplement the actions of member states, which excludes the adoption of the laws. Therefore, in Covid-19 pandemic, EU member states remained the first authorities to take the administrative and other measures. This leads to disparity of national strategies, although in the middle of March, EU proposed member states to temporary limit the non-essential travel (European Commission 2020a). 
In Slovenia, the time on Covid-19 pandemic coincided with the changes in the political arena. At the end of the January, Prime Minister Marjan Šarec resigned (Slovenska tiskovna agencija 2020a). The formation of a new government was taking place in Slovenia subsequently with the spread of the Covid-19 in Europe. A day after the World Health Organisation declared Covid-19 as pandemic, Slovenia declared Covid-19 as epidemic ('Odredba o razglasitvi epidemije', 2020). Two days later, the state got new Government and the new Prime Minister, Janez Janša (Slovenska tiskovna agencija 2020b). This was his third mandate in the sovereign Slovenia. The first decision of the new Government referring to the Covid-19 epidemic measures was formation of the 'crisis headquarter' (Eržen 2020). Jelko Kacin (one of the former Slovenian ministers for defense) was appointed as the official Spokesman.

As both key persons - the Prime Minister and the Spokesman had military educational background, they often used war rhetoric when they communicated measures to contain the virus with the public and with the members of the National Assembly. Dolar (2020) emphasized that such military terms aroused and increased panic among the people. As states usually gain enormous power in the war, the author warned that the power could be used for regressive legislation and excessive use of the military. Teršek (2020) believed that due to the communication of daily politics with the public, fear among people became more epidemic than Covid-19 epidemic itself.

\section{LIMITATIONS OF BASIC HUMAN RIGHTS AND VIEWS OF THEIR ELIGIBILITY}

The spread of the Covid-19 in the state and in the neighbouring countries (e.g. Italy) required quick governmental response. It came in the form of several decrees that temporary limited people's movement, socializing, performing business etc.

For the purpose of this study, limitations are classified into four groups, following the area of their restrictions:

- ban on free movement and gathering;

- ban on performing non-essential businesses;

- limited access to public services - health, education, public transport;

- application of safety and hygiene measures (use of face masks, physical distance, hygiene).

The often discussed topic in the period of the first declaration of the Covid-19 epidemic in Slovenia was the ban on movement and 
gathering of people, particularly the restriction of movement outside the borders of their municipality. As the latest decision of the Government was submitted to the Constitutional court for review (the decision of the Court is discussed in the next subsection), this subsection focuses on this group of bans. Other restrictions are presented to better understand the extent of the human rights limitations in the country.

\section{Restrictions on Free Movement and Gathering}

The first general ban prohibited - in the first version for non-definite period - movement and gathering of people in public places/areas in the state and prohibited access to public places/areas ('Odlok o začasni splošni prepovedi gibanja in zbiranja', 2020). There were certain exceptions to this general prohibition, e.g. going to work, buying essential goods, buying pharmaceutical products etc.

According to the strict interpretation of the decree, people should not move outdoor, except for the reason stated in the decree as an exception. Nevertheless, milder approach from the strict version of the bans was adopted in Slovenia than e.g. in Italy or Spain. People could walk outside with family members, perform individual sport activities if they respect physical distance and wear face-masks in closed spaces.

With the amended version of the decree adopted at the end of March 2020, the Government enforced the restriction of the movement of the people outside the municipality of their residence ('Odlok o začasni splošni prepovedi prepovedi gibanja izven občin', 2020). This decision was not accepted among the whole population as a necessary measure to contain the virus; it rose considerations from at least three reasons. Firstly, the measure was not based on the recommendations of the epidemiologists (Zgonik 2020). Secondly, the justification was based on unconvincing evidences presented by public representatives and certain mayors about the so-called 'mass invasion' of Slovenes to two major touristic destinations (Bled and Portorož/Piran) on the last sunny weekend in March. According to the quantity of the traffic (number of vehicles is automatically counted every day) and webcam shots the invasion has never been confirmed. Therefore, the measure was accepted more as showing the determination of the Government that they did everything to protect the population (Zgonik 2020). Thirdly, there have been some attempts in the first three weeks of the new Government to extend their authority. Government tried to transfer certain authorities from the National Assembly to itself (Čas 2020) and to extend the con- 
trol over the citizens, e.g. with controlling the movement of citizens in quarantine (as in Israel and Slovakia), with delegation of police powers to the army etc. (Trampuš 2020c; Kos 2020). Markeš (2020) believed that with the implementation of intra-municipality movement measures, the Covid-19 virus had transformed into a 'power virus': there were no professional arguments, except the position of power that overwhelmed every argument.

Several amendments of the decree relating to the limitation of movement and gathering were adopted in the following next few months of the epidemic and pandemic. At the end of April, the Government mitigated most of the strict movement restrictions. However, gathering restrictions stayed in place in form of maximum allowed people in one place (from 20 to 500 in open spaces). The last day in May was also the last day of official state of epidemic in Slovenia ('Odlok o preklicu epidemije', 2020).

Despite the limitation on gathering, the protests emerged in the cities across Slovenia, similar as in other cities around the world. Rus and Rušt (2020) marked them as spontaneous challenge to potential authoritarian tendencies of the Government and to other general issues (e.g. necessity of protection of workers' rights, environmental concerns, public health problems etc.). Protests again the restrictions also took place in Berlin, Germany. Despite the fact that some German politicians have called for the ban (due to the danger of the virus spreading), the Federal Minister of Justice believed that even in those circumstances people should be able to express their views against the current government policy (Zimic 2020). The protest in capital of Slovenia took place 25 Fridays in a row. The authorities have tolerated the protests until the severe deterioration of the epidemic situation in October 2020 (Košak 2020).

At the beginning of the epidemic, special decree was adopted to limit people crossing the state borders (land, see and air). Checkpoints, border opening times and exceptions were introduced for crossing the border with Italy and Austria in the beginning of epidemic and later for all bordering countries ('Odlok o prehodih na zunanji meji', 2020). From the declaration of pandemic until the beginning of June, it was impossible for Slovene citizens to go out of the state for no particular reason apart from those stated in the decree. For visitors, coming to Slovenia from abroad, quarantine was an obligatory measure to prevent the spread of the virus.

In June, restrictions on crossing the borders of Slovenia were gradually mitigated, following the guidelines of the $\mathrm{EU}$ (European Commission 2020b). First international transit was allowed for the citi- 
zens of Schengen $\mathrm{EU}$ member states and in July for other $\mathrm{EU}$ member states. Stricter regime than for EU member states was implemented for entering Slovenia from non-EU states. Measures (quarantine) depended mostly on their epidemiologic status of the country.

Vuksanović (2020c) pointed out two restriction measures that indicated nonequal treatment of citizens. The first one was related to Slovene citizens who own real estate or a vessel in Croatia. The ownership allowed them to travel to Croatia earlier that those Slovenes that did not have that privilege. The second non-equal treatment the author saw in obligatory quarantine for travelers arriving to Slovenia from non-EU countries. No argument was given on those issues.

Until October 2020, the decree about crossing the border have been changed several times - from mitigating restrictions in July and August to their extension during the next two months, when epidemiologic picture in Slovenia and in most countries in the $\mathrm{EU}$ was getting worse. Following the guidelines of EU (European Commission 2020c), the Government implemented restrictions according to the so-called 'semaphore colour model'. The free entry or restrictions to entry the state (quarantine) depending on the epidemiologic status of a particular country or region.

\section{Other Limitations and Restrictions}

Following the aim of ceasing the circulation of the virus, the Government closed kindergartens and schools, including universities ('Odlok o zaprtju vrtcev, šol, fakultet', 2020) the next day from declaring the epidemic. The closure of kindergatens and schools has brougth many issues, e.g. about organisation of the childcare, the loss of hot meals for some children, a greater risk of infection for granparents who will take care of children etc.

A decree from the middle of March, prohibited the offering and sale of goods and services directly to consumers, e.g. services as tourist accommodation, food and beverages, wellness, sports and recreation, cultural, hairdressing, cosmetic, pedicure, gambling ('Odlok o začasni prepovedi ponujanja', 2020). As the set of economic activities referred exclusively to services and not to goods (Vuksanović 2020a), this provision should not have been in accordance with the Infectious Diseases Act ('Zakon o nalezljivih boleznih', 2006). The Act only states the 'sale of goods', but not the 'sale of services'. Using the narrow linguistic explanation of the Act's provisions, the finding of Vuksanović (2020a) might have been correct. However, it has not been known so far if any case was brought to the Constitutional Court on this regard. On the same day, the Government also 
temporary prohibited public transport ('Odlok o začasni prepovedi javnega prevoza', 2020).

With the closing down of almost all non-essential businesses, restrictions on movement and gathering, public transport, Slovenia was actually in the state of 'lock-down'. Furthermore, at the end of March, Government discontinued all medical preventive activities and dental services other than emergency and those whose omission would lead to permanent damage to general and oral health. All specialist examiantions and surgical procedures were cancelled except those marked with a degree of urgency or emergency (e.g. oncology treatment and pregnant women) ('Odlok o prekinitivi in omejitvi zdravstvenih dejavnosti', 2020). Komel (2020) pointed out that restriction of helth treatment potentialy might have been unconstitutional, while the Government issued them with the decree and not by law. The fact that the Government addopted restrictions about availability of the health care under time preasure and in a rather unkown sitation, can not be reasonable ground for bypassing the rule of law.

The most public discussion and confusion was related to the application of hygene and safe measures, particularly to physical distance and face masks. The physical distance among people on public places and the use of face-masks were detemined with the instructions and recommentadions of the National Institute for Public Health. The Government incorporated them in their decrees related to the Covid19 pandemic.

However, the instructions and recommendations have been changing constantly (even in two or there days), explained differently by various governamental representatives and therefore brought enormous confusion among the public. The confused approach has repetedly revealed different standpoints among epidemiologists, between epidmiologists and politicans, and ignorance of the latest to explain what kind of measures functioned and which did not (Magdalenc 2020).

Johan Gieske (Sweedish epidemiologist) openly admited (in April) that there was little scientific evidence of eligibility of some measures taken by the majority of states, e.g. closure of state borders, closure of schools, restrictions of movement, mandatory use of facemasks etc. (Zgonik 2020). According to his experience, politicians are not so interested whether the measures will be actually effective, but more how the public will perceive them. E.g. the spraying disinfectant on sidewalks and houses he named a 'stupid act', which showed - on the other hand - the presence of constant government action in sense 'we protect you'. 
While Slovene politicians always presented their actions as the only appropriate and decisive ones for the protection of the population, the Slovene epidemiologists were more modest than politicians. E.g., dr. Bojana Beovič (the head of the medical group) did not hesitate to admit (Zgonik 2020) that only few decisisons made during epidemic had really good scientific background: there was much judgement and observations what other countries did; some measures could even be wrong.

It seemed that the 'herd instinct' played a major role in the adoption of restrictive measures (Zgonik 2020). States have monitored what kinds of measures were adopted in other countries. The majority of politicians quickly became afraid that they might have been accused of negligence if they had not adopted at least the same strict measures. Slovenia was no exception to the rule in that process.

From the declaration of Covid-19 as pandemic on, many actions taken by the Government when referring to the virus, was given a form of law - legal acts and measures. Thus, the question is if the technique of law has become a new way of managing people (Lovšin 2020).

\section{Constitutional Court: Intra-Municipality Movement Restriction Was a Legal Measure}

The initiative for the assessment of the constitutionality and legality of the measure of restriction of movement across municipality borders (in continuation: disputed provision) was filed at the Constitutional Court (in continuation: the Court) by a group of citizens. They claimed that disputed provision contradicted the principle of proportionality; therefore, it is not in accordance with the first paragraph of Article 32 of the Constitution of the Republic of Slovenia, which guaranties freedom of the movement ('Odločba Ustavnega sodišča' 2020).

The Court has decided in a short period that the decision of the Government, when certain measure will end or extend, is not of political but of professional nature and therefore must not be indefinitive. Thus, the time-frame of validity of the Governmental decision must be based on the (epidemiologic) expert's opinion. This decision committed the Government to the continuous monitoring and following-up the expert opinion ('Sklep Ustavnega sodišča' 2020).

By very quick first review of the initiative, the Court announced that the system of balance between the legislative and executive bodies was working despite the epidemic and that the Governmental decrees were under the constitutional review (Žerdin 2020).

Different opinions of legal/constitutional experts have been ex- 
pressed in the following months. For some (e.g. Trampuš 2020a; Teršek and Dragan 2020; Lovšin 2020; Vuksanović 2020a), restriction of movement inside municipalities seemed to be the most controversial and incomprehensible measure implemented in Slovenia (Figelj 2020). It should have been neither reasonable nor proportional with the current epidemic situation in the state, while Slovenia was far from having such epidemic situation as Italy or Spain had in March 2020 (Teršek 2020).

Despite having a similar epidemiological situation as Slovenia, the majority of Germans could travel around the state fairly smoothly (Zimic 2020); not all, while in Germany, the measures to contain the Covid-19 were under the authority of the federal states. However, the High Court in Greifswald abolished the measure of land Mecklenburg, who restricted their people access to other places. The Court stated that the travel ban was too severe measure and that people have the right to travel to the coast (Kršinar 2020). In Austria, people were not limited to stay inside the borders of municipalities, although they had worse epidemiologic situation than Slovenia (Figelj 2020).

The view of Zagorc (2020) was slightly different from the abovementioned Slovene legal experts. The author advocated the principle of precautionarity. For him, in the initial period of the epidemic, the Government as the decision-maker did not have relevant data (due to the delay of symptoms) and was actually guessing about the further evolvement of the epidemic. Nor did the Government know when certain measures would have shown the effects. Therefore, it reacted according to the legal precautionary principle, thinking to the worst scenario all the time. It is known that in real life, the precautionary measures had intense negative effects on the rights of individuals, but they were implemented to protect public interest health of people. The author emphasized that in the health care, a special challenge is the particular burden of cost-benefit techniques. The reason lies in the psychological forces, which are so violent that even judges cannot avoid them. In professional literature, there is a well-known conflict between concrete (identified) lives and statistical lives. According to the previous experiences, the choice between different paths of action systematically shows the greater value of 'concrete life'. With names and surnames, they take place ten times more before our eyes than statistical lives do.

The Constitutional Court adopted final decision in August 2020. It carried out the assessment even though the decree ceased to be valid during the procedure. The reason was that the initiative has opened 
a particularly important precedent-setting issue of a systematic nature to which the Court has not yet had the opportunity to comment; furthermore, the decision would serve as a precedent in the following similar situations ('Odločba Ustavnega sodišča' 2020). The Court conducted meritory assessment on the basis of a test of legitimacy (if by interfering the Government pursued constitutionally permissible aim) and the strict test of proportionality (assessment of the appropriateness, necessity and narrower proportionality of the interference). It decided that the disputed provision did not disproportionally interfere with the freedom of movement.

Five constitutional judges have supported the Governmental decree, four have not. Tight majority could be interpreted in the way that the opposite situation might have happened (Trampuš 202ob). Four constitutional judges wrote a separate opinion to the majority decision. One of the judges emphasized that the Court has renounced its basic mission - to control the executive branch of the Slovene legal system. The other pointed out that at least ten constitutional rights have been restricted with the Governmental decrees, but Constitutional Court simply ignored that fact.

Ribičič (2020b) commented that the fact, that in the time of judgement the decree has already been ceased, might have an influence on the more strict judgement as it would have been otherwise. Moreover, the decision of the Court might have been even more unsure if there hadn't been prior position on the constitutional conformity of the prohibition even before the proportionality test was carried out. According to the before mentioned constitutional expert, there has been evident methodological deficiency in the composition of the Constitutional Court: two Constitutional judges always confirm the standpoints of the Government that is currently in the position.

For the time being, the Constitutional Court decision - agree with it or not - is here to be respected. It is a precedence that will serve to the Government as a guideline to test how far it can go with restricting the human rights when managing the Covid-19 pandemic in the future. The fact is that political authorities might abuse crises to suspend the constitution (Ribičič 2020a). Therefore, the following decisions of the Government, restricting the human rights as the way of managing pandemic, might indicate in what kind of society we will find ourselves when the Covid-19 pandemic is over.

\section{Discussion}

The Covid-19 pandemic, the most shuttering event that happened in the 21st century, revealed the level of the (in)competency of the 
majority of the world's leaders to deal with pandemic. State authorities have been put in front of enormous challenges, when the health crisis has become an economic and social crisis, affecting even the basic human rights.

Having no vaccine for Covid-19, the non-pharmaceutical measures were (and still are) the only measures to contain the spread of the virus: limitation of movement, restriction on gathering, closing of non-essential businesses etc. Some of them severely restricted basic human rights, the right to free movement the most.

According to international human rights conventions and constitutions of the majority of democratic states, non-absolute human rights can be limited under certain circumstances and to certain extent. However, there have been some evidences in the states all over the world that governments might have used the current health crisis and restrictive measures for their own purpose, to strengthen their power. In the $\mathrm{EU}$, Hungary has become an evident case of it.

When evaluating the rights in Covid-19 pandemic, there is not doubt that the value of the society is more important than the individual rights. Therefore, setting the public interest of managing the health crisis in front of the certain individual human rights is a legitimate goal for their temporary restrictions. Yet, restrictions can be justifiable only if the measures meet certain legal standards; they have to be necessary, proportional, scientifically valid and timebounded. Constant check of those standards by national courts is the tool to prevent abuse of governments to extend their power under the pretext of protecting public interest. As Western democracies are more resilient to such attempts than younger ones, Covid-19 has put Slovenia, as a young democracy, under severe test of their constitutionality.

As there hasn't been generally accepted approach on how to restrain the virus from spreading, each state was sovereign to implement restrictions in their territory. There has been little scientific evidence at that time, which measures really contain the virus (apart from the total stay-home measures) and which do not. Some of them were based on 'trial and error' principle. The countries with worse epidemiological situation than others, implemented more severe restrictions (total quarantine, lock-down). Some measures could be understaned more as 'shows' of politicians to present how they took care of their society, the others might express the power of the state authorities over its citizens, while the rest might have been realy effective. The fact that there was a lack of experience with the spreading of the new virus might be an excuse for the governments to make 
some 'trial and error' actions. However, the pandemic goes on and further actions of governments should be under more severe judgement as were those in the first wave of Covid-19 outburst.

\section{Conclusions and Applications}

The paper synthesises and critically discusses how the Government of Slovenia have managed the situation in the time of the first wave of Covid-19 in the state (from March until October 2020). It presents crucial regulations, acts, events and standpoints of the public, legal and medical experts and scholars published in this period.

The insight in Governmental management of the Covid-19 situation in Slovenia reveals comparable approaches and events to those in other countries: severe interference in basic human rights, use of war rhetoric, protests of disagreed part of citizens, initiatives for assessing conformity of governmental decrees with constitutional rights and attempts of extending the power of executive bodies.

The results show that the Government have managed the epidemic time mostly with legal acts, governmental decrees, which can be classified according to the areas of restrictions. During the days following the declaration of epidemic in the country, six crucial sectorial decrees were adopted, with more than 50 amendments in the next couple of months. Such managerial approach of the Government indicates that in practice, the technique of law has been used to manage people. Constant changes have raised confusion among citizens and severe disagreements of so many exceptions to general restrictions, as they have put people under different treatment (the problem of equality).

The findings reveal a polarized opinion among public, legal and medical experts, if all measures were proportionate to the epidemiologic situation in the state. Even when the most controversial restriction measure (intra-municipality movement) has passed the assessment of its constitutionality and become an important precedence for the consequent governmental decisions, the polarization continued. Moreover, the decision of the Constitutional Court itself has raised serious considerations among legal experts, which might be - or not - considered in the following assessments of governmental restrictions by the Court. As the Government in October 2020 again declared epidemic, it is assumed that there will be more initiatives filled to Constitutional Court against its restrictions (e.g. police hour).

Some limitations related to this study need to be mentioned. The first one is subjectivity of the researcher, which commonly accompanies the collection, selection and analysis of the non-numerical 
data. The second limitation relates to the limited number of documents available on the research topics and their quality. In academia, some of the resources used in this research might be characterised by the term 'grey literature' or papers 'more driven by practice than research'. However, the fact is that there have not yet been many studies on the topic. The study is geographically limited to Slovenia, even though some comparisons with other countries have been mentioned.

\section{References}

Amon, J. J. 2020. 'Covid-19 and Detention: Respecting Human Rights.' Health and Human Rights Journal 22 (1): 367-70.

Amon, J. J., and M. Wurth. 2020. 'A Virtual Roundtable on covid-19 and Human Rights with Human Rights Watch Researchers.' Health and Human Rights Journal 22 (1): 399-413.

Council of Europe. 2020. 'Secretary General Writes to Victor Orban Regarding covid-19 State of Emergency in Hungary.' Newsroom, 24 March. https://www.coe.int/en/web/portal/-/secretary-generalwrites-to-victor-orban-regarding-covid-19-state-of-emergency-inhungary.

Čas, T. 2020. 'Sodelovanje vojske pri izvajanju nalog policije.' Dnevnik, 28 March. https://www.dnevnik.si/1042925786.

Dolar, R. 2020. 'Koronavirus v metaforah.' Mladina, 4 April. https://www .mladina.si/197549/koronavirus-v-metaforah/.

Drinóczi, T., in A. Bień-Kacała. 2020. 'covid-19 in Hungry and Poland: Extraordinary Situation and Illiberal Constitutionalism.' The Theory and Practice of Legislation 8 (1-2): 171-92.

European Commission. 2020a. 'Communication from the Commission to the European Parliament, The European Council and the Council Covid-19: Temporary Restriction on Non-Essential Travel to the EU.' сом/2020/115 final, European Commisson, Brussels.

- 202ob. 'Communication from the Commission to the European Parliament, The European Council and the Council on the third assessment of the Application of the Temporary Restriction on NonEssential Travel to the Eu.' сом(2020) 399 final, European Commisson, Brussels.

- 2020c. 'Proposal for Council Recommendation on a Coordinated Approach to the Restriciton of Free Movement in Response to the covid-19 Pandemic.' сом(2020) 499 final, European Commission, Brussels.

'European Convention on Human Rights.' 1950. https://www.echr.coe .int/Documents/Archives_1950_Convention_ENG.pdf.

Eržen, B. 2020. 'Vlada ustanovila krizni štab in opravila menajve na čelu policije in vojske.' Delo, 14 March. https://www.delo.si/novice/ 
slovenija/vlada-ustanovila-krizni-stab-in-opravila-menjave-na -celu-policije-in-vojske/.

Figelj, M. 2020. 'Morala med epidemijo ali kaj so nam ukradli.' Dnevnik, 16 May. https://www.dnevnik.si/1042929473.

'International Covenant on Human and Political Rights.' 1967. https:// treaties.un.org/doc/Treaties/1976/o3/19760323\%2006-17\%20AM/Ch _IV_04.pdf

Komel, P. 2020. 'Pravica do zdravstvenega varstva v času covida-19.' Dnevnik, 26 August. https://www.dnevnik.si/1042937233.

Kos, S. 2020. 'Koronavirus in čovekove pravice: predlagana širitev pooblastil policije za zajezitev epidmeije sproža številne dileme.' Delo, 31 March.

Košak, K. 2020. 'Vlada želi končati “fešte” in proteste.' Dnevnik, 8 October. https://www.dnevnik.si/10429406o8/slovenija/video-hojs -od-jutri-zbiranje-ljudi-omejeno-na-najvec-10-ljudi-policija-strogo -nad-petkove-protestnikeike.

Kršinar, I. 2020. 'Osvoboditev iz občin.' Reporter, 4 May.

Lebret, A. 2020. 'Covid-19 Pandemic and Derogation to Human Rights.' Journal of Law and the Bioscience 7 (1): Isaa015. https://doi.org/10 $.1093 / \mathrm{jlb} / \mathrm{lsaa015}$.

Lovšin, P. 2020. 'Dr. Andraž Teršek, ustavni pravnik: Ohranjam upanje, da se ljudje ne bodo pustili poneumiti.' Dnevnik, 19 September.

Magdalenc, L. 2020. 'Premalo vas je strah.' Dnevnik, 19 September.

Markeš, J. 2020. 'O tako imenovani stroki.' Delo, 7 April.

Meßerschmidt, K. 2020. 'Covid-19 Legislation in the Light of the Precautionary Principle.' The Theory and Practice of Legislation 8 (3): $1-26$.

Miles, M. B., A. M. Huberman, and J. Sandaña. 2014. Qualitative Data Analysis: A Method Sourcebook. Los Angeles: Sage.

'Odločba Ustavnega sodišča U-I-83/20-36.' 2020. Uradni list Republike Slovenije, št. 128. https://www.uradni-list.si/1/objava.jsp?sop=202001-2291.

'Odlok o odrejanju in izvajanju ukrepov, povezanih s preprečevanjem širjenja covid-19, na mejnih prehodih na zunanji meji in na kontrolnih točkah na notranjih mejah Republike Slovenije.' 2020. Uradni list Republike Slovenije, št. 50. https://www.uradni-list.si/1/ objava.jsp?sop=2020-01-0775.

'Odlok o preklicu epidemije nalezljive bolezni SARS-Cov-2 (covID-19).' 2020. Uradni list Republike Slovenije, št. 68. https://www.uradnilist.si/1/objava.jsp?sop=2020-01-1030.

'Odlok o začasni prepovedi in omejitvah javnega prevoza potnikov v republiki Sloveniji.' 2020. Uradni list Republike Slovenije, št. 24. https://www.uradni-list.si/1/objava.jsp?sop=2020-01-0566.

'Odlok o začasni prepovedi ponujanja in prodajanja blaga in storitev potrošnikom v Republiki Sloveniji.' 2020. Uradni list Republike Slo- 
venije, št. 25. https://www.uradni-list.si/1/objava.jsp?sop=2020-01 -0570.

'Odlok o začasni splošni prepovedi gibanja in zbiranja ljudi na javnih mestih in površinah $\mathrm{v}$ Republiki Soveniji.' 2020. Uradni list Republike Slovenije, št. 30. https://www.uradni-list.si/1/objava.jsp?sop= 2020-01-0602.

'Odlok o začasni splošni prepovedi gibanja in zbiranja ljudi na javnih mestih in površinah $\mathrm{v}$ Republiki Sloveniji ter prepovedi gibanja izven občin.' 2020. Uradni list Republike Slovenije, št. 38. https://www .uradni-list.si/1/objava.jsp?sop=2020-01-0688.

'Odlok o začasni prepovedi zbiranja ljudi v zavodih s področja vzgoje in izobraževanja ter univerzah in samostojnih visokošolskih zavodih.' 2020. Uradni list Republike Slovenije, št. 25. https://www.uradnilist.si/1/objava.jsp?sop=2020-01-0568.

'Odlok o začasnih ukrepih na področju zdravstvene dejavnosti zaradi zajezitve in obvladovanja epidemije covid-19.' 2020. Uradni list Republike Slovenije, št. 40. https://www.uradni-list.si/1/objava.jsp?sop =2020-01-0708.

'Odredba o razglasitvi epidemije nalezljive bolezni sARs-Cov-2 (covid19) na območju Republike Slovenije.' 2020. Uradni list Republike Slovenije, št. 19. https://www.uradni-list.si/1/objava.jsp?sop=202001-0532.

Office of the United Nations High Commissioner for Human Rights. 2020a. 'Coronavirus: Human Rights Need to be Front and Centre in Response, says Bachelet.' 6 March. https://www.ohchr.org/EN/ NewsEvents/Pages/DisplayNews.aspx?NewsID=25668

- 2020b. 'Covid-19: States Should Not Abuse Emergency Measures to Suppress Human Rights - un Experts.' 16 March. https://www .ohchr.org/EN/NewsEvents/Pages/DisplayNews.aspx?NewsID $=25722$.

Organisation for Economic Co-Operation and Development. 2020. 'Tourism Policy Responses to coronavirus (covid-19).' https://www .oecd.org/coronavirus/policy-responses/tourism-policy-responses -to-the-coronavirus-covid-19-6466aa2o/.

Podkrižnik, M. 2020. 'Vojni diskurz, ki se širi skupaj z virusom, je netočen in neumesten.' Delo, Sobotna priloga, 4 April.

Ribičič, C. 2020a. 'Kaj nas bo naučila kriza: sorazmernost in avtoritarnost.' Dnevnik, 15 April. https://www.dnevnik.si/1042927929/ slovenija/kaj-nas-bo-naucila-kriza-sorazmernost-in-avtoritarnost.

- 2020b. 'O pogumu in kritiki.' Dnevnik, Objektiv, 12 October.

Richardson, E., and C. Devine. In press. 'Emergencies and Eventually: How to Bette Analyze Human Rights Restrictions Sparked by Covid19 Pandemic Unter International Covenant on Civil and Political Rights.' Michigan Journal of International Law. 
Rus, U., and M. Rušt, M. 2020. 'Kaj druži “leve fašiste” in "kaviar socialiste."' Dnevnik, 13 July.

Ryan, M. 2020. 'In Defence of Digital Contact-Tracing: Human Rights, South Korea and Covid-19.' International Journal of Pervasive Computing and Communications 16 (4): 383-407.

'Sklep Ustavnega sodišča št. U-I-83/20-10.' 2020. Uradni list Republike Slovenije, št. 58. https://www.uradni-list.si/1/objava.jsp?sop=202001-0843.

Slovenska tiskovna agencija. 2020a. 'Šarec odstopil s položaja premiera.' 27 January. https://www.sta.si/v-zivo/odstopsarec.

- 2020b. 'Slovenija dobila 14. vlado.' 14 March. https://www.sta.si/ v-srediscu/vlada2020.

Snyder, H. 2019. 'Literature Review as a Research Methodology: An Overview and Guidelines.' Journal of Business Research 104:333-39.

Spadaro, A. 2020. covid-19: 'Testing the Limits of Human Rights.' European Journal of Risk Regulation 11 (2): 317-25.

Teršek, A. 2020. 'O zakonitosti in ustavnosti ukrepov in omejitev: ustavne pravice med uradno epidemijo.' Dnevnik, 11 July. https://www .dnevnik.si/1042933835.

Teršek, A., in J. Dragan. 2020. 'Ustavnopravna analiza omejitve ustavnih pravic v času pandemije.' Javna uprava 56 (1-2): 85-102.

Trampuš, J. 2020a. 'Dr. Rajko Pirnat: Demokracija ne deluje na podlagi hitrega odločanja.' Mladina, 24 April.

- 2020b. 'Bianco menica.' Mladina, 25 September. https://www .mladina.si/201501/bianco-menica/.

— J. 2020c. 'Vlada krši pravila pravne države in načelo zakonitosti.' Mladina, 3 April.

Valerio, C. 2020. 'Human Rights and Covid-19 Pandemic.' JBRA Assisted Reproduction 24 (3): 379-81.

Vuksanović, I. 2020a. 'Tehtanje med konkretnimi in statističnimi življenji.' Delo, 18 April.

- 2020b. 'Kako zagotoviti sorazmernost odziva na epidemijo covida-19? Ustavno sporna prepoved gibanja.' Dnevnik, 28 March. https://

www.dnevnik.si/1042925777.

- 2020c. 'Preventivno zapiranje brez podlage.' Dnevnik, 22 August. https://www.dnevnik.si/1042936942.

'Zakon o nalezljivih boleznih - zNB (uradno prečiščeno besedilo) (zNBUPB 1).' 2006. Uradni list Republike Slovenije, št. 33. https://www .uradni-list.si/1/objava.jsp?sop=2006-01-1348.

Zimic, B. 2020a. 'Slovenija vs. Nemčija.' Delo, 14 April. 202ob. 'Prepovedi protestov ne bo.' Delo, 8 August.

Zgonik, S. 2020a. 'Ivan Eržen: Po mojem mnenju najnovejši drastični ukrepi niso bili potrebni. S strokovnega vidika jih ne morem zagovarjati.' Mladina, 3 April. 
- 2020b. 'Priprave na maraton.' Mladina, 24 April.

Zupančič, B. M. 2004. 'Mednarodna sodna presoja in internacionalizacija ustavnega prava.' http://www.us-rs.si/media/govor_dan _ustavnosti_2004.pdf.

Žerdin, A. 2020. 'Ustava ali epidemija.' Delo, 18 April. 